January 2000 • NREL/SR-520-27513

\title{
A Preliminary Analysis of Block Island Power Company's Use of Clean Distributed Resources to Provide Power to Its Customers
}

\section{Technical Report: August 1998}

T.E. Hoff

Pacific Energy Group

Walnut Creek, California

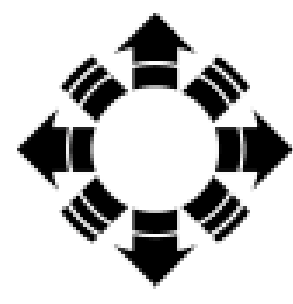

\section{NPEI}

National Renewable Energy Laboratory

1617 Cole Boulevard

Golden, Colorado 80401-3393

NREL is a U.S. Department of Energy Laboratory

Operated by Midwest Research Institute $\bullet$ Battelle $\bullet$ Bechtel

Contract No. DE-AC36-99-G010337 


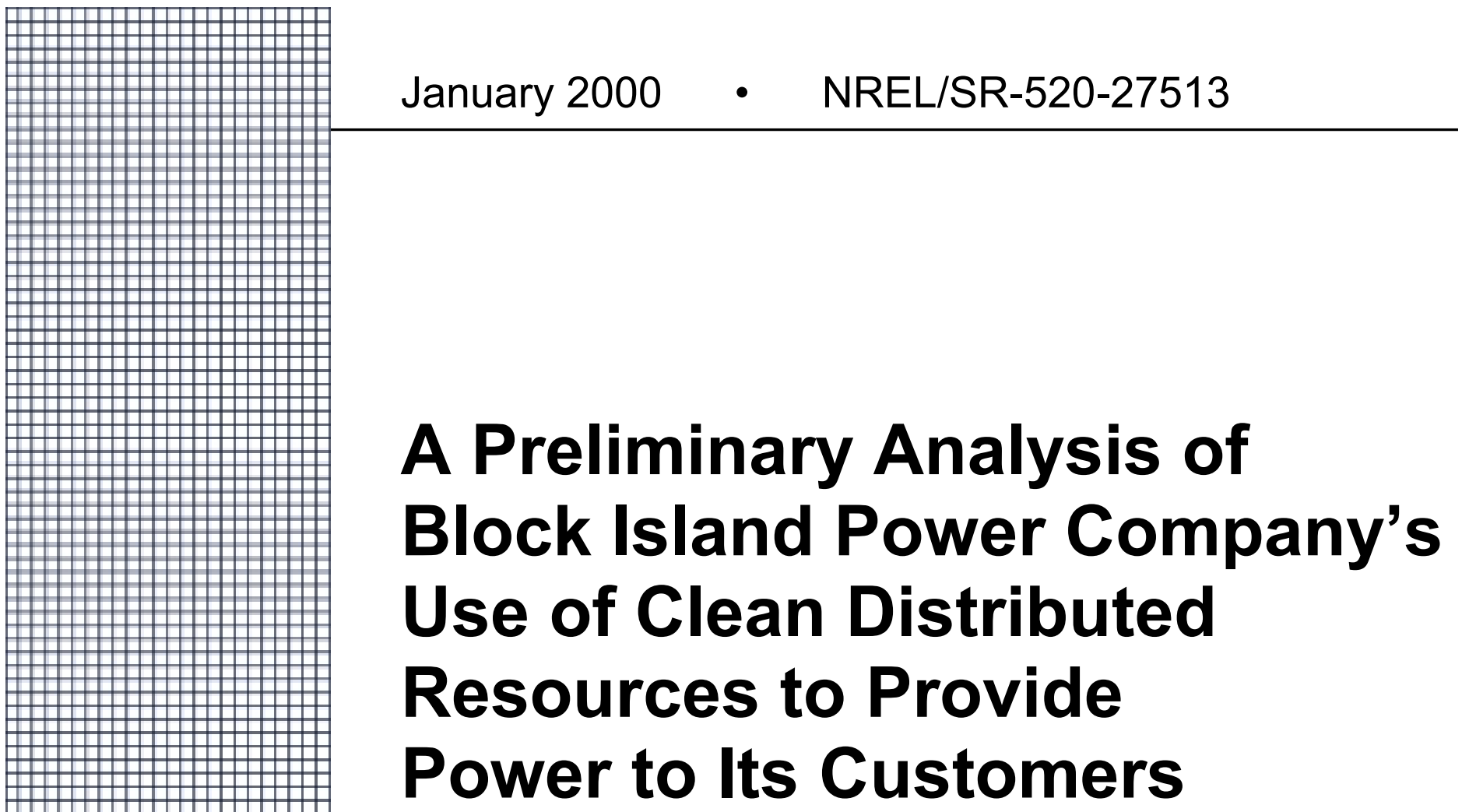

\section{Technical Report: August 1998}

T.E. Hoff (presently with Clean Power Research)

Pacific Energy Group

Walnut Creek, California

NREL Technical Monitor: C. Herig

Prepared under Subcontract No. XAX-6-16817-01

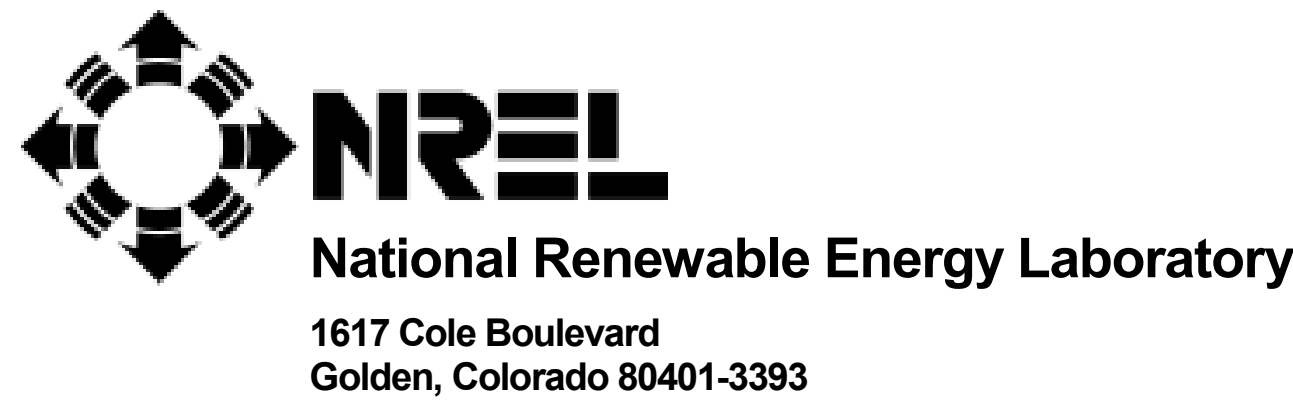

NREL is a U.S. Department of Energy Laboratory

Operated by Midwest Research Institute $\bullet$ Battelle $\bullet$ Bechtel

Contract No. DE-AC36-99-G010337 


\section{NOTICE}

This report was prepared as an account of work sponsored by an agency of the United States government. Neither the United States government nor any agency thereof, nor any of their employees, makes any warranty, express or implied, or assumes any legal liability or responsibility for the accuracy, completeness, or usefulness of any information, apparatus, product, or process disclosed, or represents that its use would not infringe privately owned rights. Reference herein to any specific commercial product, process, or service by trade name, trademark, manufacturer, or otherwise does not necessarily constitute or imply its endorsement, recommendation, or favoring by the United States government or any agency thereof. The views and opinions of authors expressed herein do not necessarily state or reflect those of the United States government or any agency thereof.

Available electronically at http://www.doe.gov/bridge

Available for a processing fee to U.S. Department of Energy

and its contractors, in paper, from:

U.S. Department of Energy

Office of Scientific and Technical Information

P.O. Box 62

Oak Ridge, TN 37831-0062

phone: 865.576.8401

fax: 865.576.5728

email: reports@adonis.osti.gov

Available for sale to the public, in paper, from:

U.S. Department of Commerce

National Technical Information Service

5285 Port Royal Road

Springfield, VA 22161

phone: 800.553.6847

fax: 703.605.6900

email: orders@ntis.fedworld.gov

online ordering: http://www.ntis.gov/ordering.htm

Printed on paper containing at least $50 \%$ wastepaper, including $20 \%$ postconsumer waste 


\section{Table of Contents}

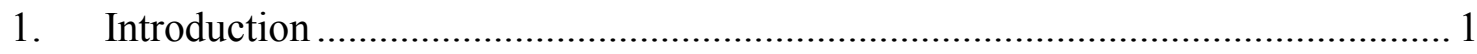

2. System Description .............................................................................. 1

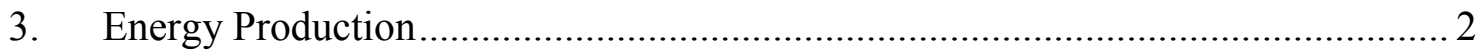

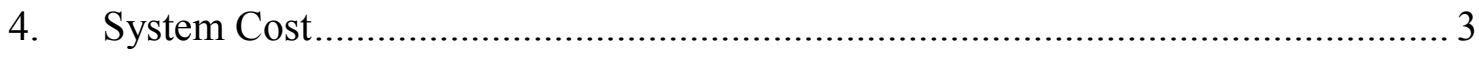

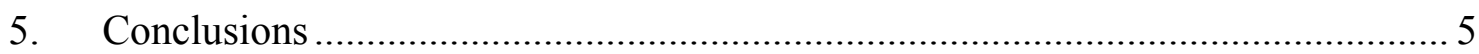

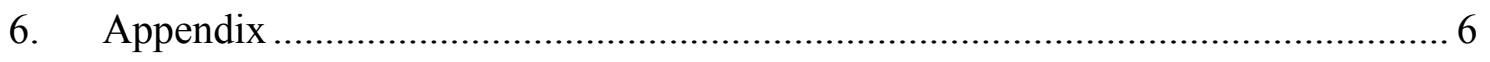




\section{Introduction}

This report is an analysis of the potential for Block Island Power Company (BIPCO) to use renewable energy and clean distributed resources to supply power to its customers. The report is only a preliminary evaluation; it does not make a final recommendation as to the action that BIPCO should take. Rather, its purpose is to indicate whether or not further analysis is warranted.

Block Island is located approximately 10 miles off the cost of the Rhode Island mainland. BIPCO currently supplies power to its customers using diesel generators. For a variety of reasons, BIPCO will make major investments in new capital to provide power to its customers. The two basic alternatives that have been suggested are: (1) to install a submarine cable to provide electricity from the mainland to the island; and (2) to purchase new cleaner power generators. This work evaluates the feasibility of a third alternative: (3) to invest in clean distributed resources.

\section{System Description}

It is proposed that the clean distributed resources be composed of: energy efficient lights and refrigerators; photovoltaic (PV) systems distributed to where power is consumed; two wind turbines; and commercial and residential cogeneration. The energy efficient lights and refrigerators will reduce electrical consumption. The PV systems will convert sunlight into electricity. The wind systems will convert wind into electricity. The cogeneration units will use fuel to simultaneously produce electricity and also heat for hot water. The investments could be made according to the following time frame.

\section{$\underline{1999}$}

- Replace 20,000 incandescent light bulbs with fluorescent lights (compact fluorescent lights or the equivalent) in residences, hotels, and restaurants; this corresponds to 2 lights for each person during the peak summer months

- Replace existing refrigerators with high efficiency refrigerators for all year round residential customers

- Install two 500-kW wind turbines (1 MW of wind)

- Install fifty 20-kW PV systems at or near demand service customer premises (1 MW of PV)

- Install six 250-kW cogeneration generators to supply hot water to demand service customers (1.5 MW of cogeneration)

- Operate the existing diesel generators to provide 15 percent of the power sold and to provide emergency peaking power ${ }^{1}$

\section{$\underline{2004}$}

- Install 1-kW cogeneration fuel cells in year round customer residences in place of their water heaters ( $0.3 \mathrm{MW}$ of residential cogeneration)

\footnotetext{
${ }^{1}$ This corresponds to less than 350 hours per year of full operation for units \#13, \#19, and \#20 (combined capacity of $3,836 \mathrm{~kW}$ ).
} 
- Operate the existing diesel generators to provide 5 percent of the power sold and to provide emergency peaking power

\section{Energy Production}

It is estimated that this system will need to produce 8.3 Million $\mathrm{kWh}$ to provide 7.7 Million $\mathrm{kWh}$ to the customers. ${ }^{2}$ Table 1 presents the distribution of electricity production (and savings) on an annual basis.

Since the some of the technologies are non-dispatchable, the match between supply and demand on a finer time scale is an important consideration. The data available at the time of the analysis was monthly. Figure 1 suggests that there is a good match between supply and demand on a monthly basis. ${ }^{3}$

Table 1. Percent of annual energy production and savings by source.

\begin{tabular}{|c|c|c|c|c|c|c|}
\hline Efficiency & Wind & $\begin{array}{c}\text { Commercial } \\
\text { Cogeneration }\end{array}$ & $\begin{array}{c}\text { Residential } \\
\text { Cogeneration }\end{array}$ & PV & $\begin{array}{c}\text { Diesel } \\
\text { Backup }\end{array}$ & Total \\
\hline $25 \%$ & $19 \%$ & $29 \%$ & $8 \%$ & $21 \%$ & $5 \%$ & $107 \%$ \\
\hline
\end{tabular}

\footnotetext{
${ }^{2}$ It is anticipated that the system will have fewer losses because the technologies will be located nearer the customers' premises. 8.8 and 7.7 Million kWh of electricity were produced and sold in 1996, respectively; it is estimated that the use of distributed resources will reduce the system losses from 15 percent to 7 percent.

${ }^{3}$ The monthly production of electricity was determined as follows. The energy efficiency savings were assumed to be proportional to the demand since these type of energy efficiency investments tend to have stable reductions throughout the year. The PV output was based on the percentage of horizontal insolation by month from NREL's solar database. The wind output was obtained from Tony Jimenez at NREL.

Residential cogeneration was assumed to be constant throughout the year since the heat load is for water heating needs. Commercial cogeneration was the residual of demand minus the other components; no monthly data were available to verify the commercial cogeneration. This pattern of production, however, appears to be reasonable because the demand customers will have hot water demand that is highly correlated with the number of people on the island.
} 


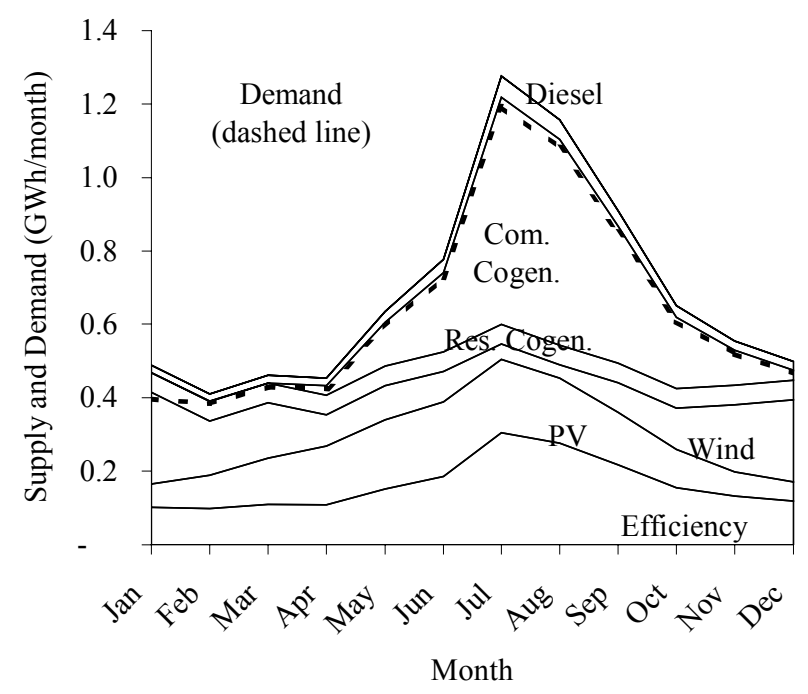

Figure 1. There is a good monthly match between supply and demand.

\section{System Cost}

Table 2 indicates that this system would have a capital cost of $\$ 8$ Million dollars. Including the other annual costs, this translates to a total annual cost of about $\$ 2$ Million starting in $1999 .{ }^{4}$ Figure 2 presents the annual cost of the system from 1999 to 2028 ; two cost estimates for the cable alternative (one included in the BIPCO Power Requirements Study, April 1998 and the other from Booth \& Associates, May 1997) are included for comparison.

\footnotetext{
${ }^{4}$ The calculations make the following assumptions: the discount rate is $5.75 \%$; there is no inflation with capital costs when the technologies need to be replaced (it appears that the costs of the renewable technologies are declining over time); there is $4 \%$ inflation for fuel and O\&M costs; property taxes are $0.5 \%$ of capital cost; insurance is $0.75 \%$ of capital cost; and the base cost for operations is $\$ 929,351$. It is also assumed that, while the energy efficiency investments have a 10 year life, BIPCO will need to make the investment in efficiency only once; customers will make the investment in subsequent years.
} 
Table 2. 1999 system cost. $^{5}$

\begin{tabular}{|l|c|c|c|c|c|c|c|}
\hline & Efficiency & Wind & $\begin{array}{c}\text { Com. } \\
\text { Cogen. }\end{array}$ & $\begin{array}{c}\text { Res. } \\
\text { Cogen. }\end{array}$ & PV & $\begin{array}{c}\text { Diesel } \\
\text { Backup }\end{array}$ & Total \\
\hline Capital Cost $(\$)$ & $\$ 500,000$ & $\$ 1,000,000$ & $\$ 2,000,000$ & $\$ 500,000$ & $\$ 4,000,000$ & - & $\$ 8,000,000$ \\
\hline Size $(\mathrm{MW})$ & & 1.0 & 1.5 & 0.3 & 1.0 & - & \\
\hline Life (years) & 10 & 15 & 15 & 15 & 30 & - & \\
\hline Elec. Prod. (GWh/y) & 2.0 & 1.5 & 2.2 & 0.6 & 1.6 & 0.4 & 8.3 \\
\hline O\&M cost $(\$ / \mathrm{kWh})$ & - & $\$ 0.02$ & $\$ 0.05$ & $\$ 0.05$ & $\$ 0.01$ & $\$ 0.02$ & \\
\hline Fuel Cost $(\$ \mathrm{kWh})$ & - & - & - & - & - & $\$ 0.08$ & \\
\hline Annualize Factor & 0.1343 & 0.1013 & 0.1013 & 0.1013 & 0.0707 & & \\
\hline
\end{tabular}

ANNUAL COSTS

\begin{tabular}{|l|c|c|c|c|c|c|c|}
\hline Cap. Cost $(\$ / \mathrm{yr})$ & $\$ 67,132$ & $\$ 101,288$ & $\$ 202,575$ & $\$ 50,644$ & $\$ 282,865$ & $\$ 0$ & $\$ 704,503$ \\
\hline Property Tax $(\$ / \mathrm{yr})$ & & $\$ 5,000$ & $\$ 10,000$ & $\$ 2,500$ & $\$ 20,000$ & $\$ 0$ & $\$ 37,500$ \\
\hline Insurance $(\$ / \mathrm{yr})$ & & $\$ 7,500$ & $\$ 15,000$ & $\$ 3,750$ & $\$ 30,000$ & $\$ 0$ & $\$ 56,250$ \\
\hline O\&M Cost $(\$ / \mathrm{yr})$ & & $\$ 29,692$ & $\$ 111,526$ & $\$ 32,073$ & $\$ 15,768$ & $\$ 7,671$ & $\$ 196,730$ \\
\hline Fuel Cost $(\$ / \mathrm{kWh})$ & & - & - & - & - & $\$ 30,685$ & $\$ 30,685$ \\
\hline
\end{tabular}

\begin{tabular}{|c|r|}
\hline Annual Cost & $\$ 1,025,668$ \\
\hline Base Cost & $\$ 929,351$ \\
\hline Total Cost & $\$ 1,955,019$ \\
\hline
\end{tabular}

\section{There are several things to notice in the table:}

1. The total capital cost is $\$ 8$ Million and the annual cost is starts out at about $\$ 2$ Million per year in 1999 (the costs increase slowly over time); these costs are comparable to the cost of power using the submarine cable.

2. While there are O\&M costs for the cogeneration, there are no fuel costs. The reason for this is as follows. Customers currently purchase and burn fuel to heat their hot water. Rather than having the customers purchase the fuel for their hot water and BIPCO purchase fuel for its generating units, BIPCO will purchase the fuel for the cogeneration units, run the cogeneration units to generate both heat and electricity, and then sell the heat to the customers. The money that BIPCO will spend on fuel will be offset by the revenue from customers for the hot water because this is the amount customers would have had to spend on fuel without the cogeneration. ${ }^{6}$

3. The two cable cost estimates differ in later years. The major reason for the difference is because the estimate in the BIPCO Power Requirements Study assumes that there is no inflation in electricity costs while the Booth \& Associates estimate assumes that there is 4 percent escalation. This emphasizes one risk that BIBCO faces with providing power using the cable: BIPCO may need to increase rates if its suppliers increase its electricity prices. If this happens, the distributed resources will make it increasingly attractive for customers to self-generate and BIPCO could lose customers.

\footnotetext{
${ }^{5}$ This table includes the cost of the residential cogeneration even though it is not installed until 2004.

${ }^{6}$ The average efficiency of hot water heating units in the U.S. is around 60 percent. It is assumed that the cogeneration units have a thermal efficiency of 60 percent and an electrical efficiency of 25 percent.
} 
4. The system with clean distributed resources may offer customers more rate stability over time because a much smaller portion of the overall cost is due to fuel costs.

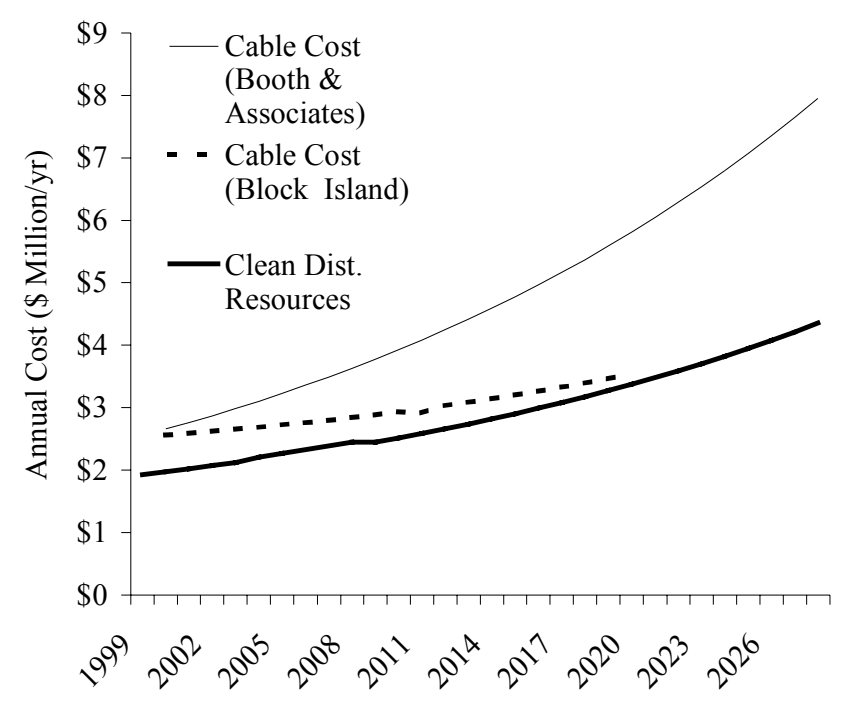

Figure 2. Annual costs.

\section{Conclusions}

The preliminary conclusion of this work is that a system composed of clean distributed resources has the potential to be a technically and economically feasible alternative for BIPCO. This conclusion suggests that a more detailed analysis of such a system is warranted.

The subsequent analysis should address these, as well as other, issues:

1. The costs for the various technologies were estimated in this report. These estimates need to be verified by obtaining bids from suppliers.

2. No discussion was included in this report about the impact on rates. That is, while the total cost of this system may be comparable to the cost of the cable based system, less electricity will be consumed. Thus, while the average bills (\$ per year per customer) will remain the same, rates ( $\$$ per $\mathrm{kWh})$ may increase.

3. This work assumed that the output from the cogeneration units that supply hot water to the commercial customers will peak in the summer because there will be a high correlation between the use of hot water and the number of people on the island. The hot water usage pattern needs to be confirmed.

4. The cogeneration investments assume that customers will be willing to participate; this needs to be verified.

5. The analysis assumed that there is a good potential for electricity savings using energy efficiency investments on the island and that customers will allow BIPCO to install the new efficient technologies (at no cost to them). This needs to be verified. 
6. While there is a good monthly match between supply and demand, the match needs to be examined on a fined time scale, such as on an hourly basis. It needs to be determined whether or not the wind output plus the PV output exceed demand, particularly during the winter months.

\section{Appendix}

This appendix describes some of the calculations in more detail.

\section{Efficiency Investments}

Suppose that the utility purchases and installs 2 compact fluorescent lights (CFL) for every person on the island. At the peak time, there are about 10,000 people on the island Table 3 suggests that this would result in the installation of 20,000 CFLs and have a total energy savings of 1.3 Million kWh hours. If each bulb cost $\$ 10$ to purchase and $\$ 2.50$ to install, ${ }^{7}$ the capital cost of this investment is $\$ 250,000$. Since the CFLs have a rated life of 10,000 hours, the bulbs will last about 10 years.

In addition, suppose that the utility purchases a high efficiency refrigerator for each of its year round residential customers. Table 4 shows that this would result in an annual savings of $666,000 \mathrm{kWh}$. The cost of this savings would be about $\$ 250,000$ if each refrigerator cost $\$ 750$.

Table 5 suggests that investing in high efficiency lights and refrigerators will cost $\$ 500,000$ and save 2 Million $\mathrm{kWh}$ or about 26 percent of Block Island's electricity consumption. Due to the type of efficiency investments, it is assumed that the energy savings are proportional to the load throughout the year. We will assume that the utility makes the energy investments once and pays for them over 10 years and then the residents and businesses pay the replacement costs of these units in the future.

\footnotetext{
${ }^{7}$ The utility could hire two people for a year at $\$ 25,000$ per year per person to install the lights. Each person would need to install 5 lights per hour (or the equivalent of about one house per hour) to accomplish this task.
} 
Table 3. Annual electricity savings from fluorescent lights.

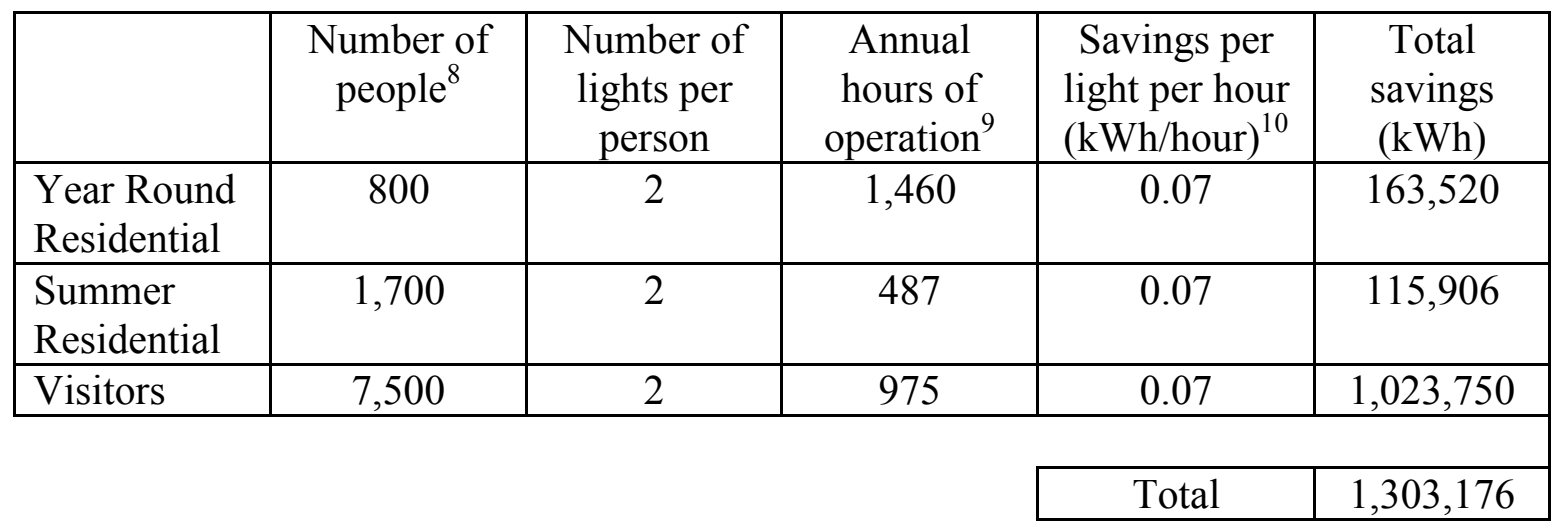

Table 4. Annual electricity savings from high efficiency refrigerators.

\begin{tabular}{|c|c|c|c|}
\hline & $\begin{array}{c}\text { Number of } \\
\text { residences }^{11}\end{array}$ & $\begin{array}{c}\text { Annual savings } \\
\text { per refrigerator } \\
(\mathrm{kWh})^{12}\end{array}$ & $\begin{array}{c}\text { Total savings } \\
(\mathrm{kWh})\end{array}$ \\
\hline $\begin{array}{c}\text { Year Round } \\
\text { Residential }\end{array}$ & 333 & 2,000 & 666,000 \\
\hline
\end{tabular}

Table 5. Energy efficiency cost and savings.

\begin{tabular}{|c|c|c|}
\hline & Savings & Installed Cost \\
\hline Lights & $1,303,176 \mathrm{kWh}$ & $\$ 250,000$ \\
\hline Refrigerators & $666,000 \mathrm{kWh}$ & $\$ 250,000$ \\
\hline & & \\
\hline Total & $1,969,176 \mathrm{kWh}$ & $\$ 500,000$ \\
\hline
\end{tabular}

\footnotetext{
${ }^{8}$ There are 1,017 residential customer accounts. It is estimated that there are about 333 active accounts in the winter (average of 2.4 people per house).

${ }^{9}$ The annual hours of operation is based on the following: 4 hours per day for year round residential customers, 4 hours per day from June through September for Summer residential customers, and 8 hours per day from June through September for visitors (i.e., in hotels, restaurants, etc.)

${ }^{10}$ This savings is based on a 30 Watt fluorescent replacing a 100 Watt incandescent.

${ }^{11}$ This assumes that there average number of people per house on Block Island is the same as the Rhode Island's average of 2.4 people per house.

${ }^{12}$ This assumes that the existing refrigerators consume about 2,500 $\mathrm{kWh}$ per year and that the new refrigerators will consume $500 \mathrm{kWh}$ per year.
} 


\section{PV and Wind Output}

Table 6 presents the estimated electricity output from PV and wind units on Block Island. The data are presented in units of $\mathrm{kWh}$ per $\mathrm{kW}$ of investment.

Table 6. Monthly electricity production for PV and wind

\begin{tabular}{|c|c|c|}
\hline & $\begin{array}{c}\text { PV Output } \\
(\mathrm{kWh} / \mathrm{kW})\end{array}$ & $\begin{array}{c}\text { Wind Output } \\
(\mathrm{kWh} / \mathrm{kW})\end{array}$ \\
\hline Jan & 63 & 250 \\
\hline Feb & 91 & 148 \\
\hline Mar & 126 & 150 \\
\hline Apr & 160 & 85 \\
\hline May & 189 & 93 \\
\hline Jun & 204 & 82 \\
\hline Jul & 200 & 41 \\
\hline Aug & 178 & 36 \\
\hline Sep & 144 & 80 \\
\hline Oct & 104 & 112 \\
\hline Nov & 65 & 183 \\
\hline Dec & 53 & 224 \\
\hline
\end{tabular}

\section{Cogeneration}

Assume that the population of Block Island is 800 people for 8 months of the year and 10,000 for 4 months of the year. Assume that the average person uses 10 gallons of propane per month for water heating. This suggests that about 464,000 gallons of propane are used per year on Block Island for water heating. Since the average gas water heater in the U.S. has about a 60 percent thermal efficiency, these units could be replaced with cogeneration units that have 60 percent thermal and 25 percent electric efficiency and would produce electricity with no additional consumption of fuel. If BIBCO could provide all of the hot water needs of its customers, it would produce about 3.1 Million $\mathrm{kWh}$ per year as well as the heat for the hot water. ${ }^{13}$

\footnotetext{
${ }^{13} 3.1$ Million $\mathrm{kWh}=464,000$ gallons of propane $* 91,220 \mathrm{BTU}$ 's/gallon $* 0.000293 \mathrm{kWh} / \mathrm{BTU} * 0.25$
} 
Prepared by:

Thomas E. Hoff, Ph.D.

Presently Employed by:

Clean Power Research

10 Glen Court, Napa, California 94558

phone: (707) 224-9992 email: tomhoff@clean-power.com

Internet: www.clean-power.com

August 5, 1998 


\section{\begin{tabular}{|l|l}
\hline REPORT DOCUMENTATION PAGE & Form Apporoved \\
\hline
\end{tabular}}

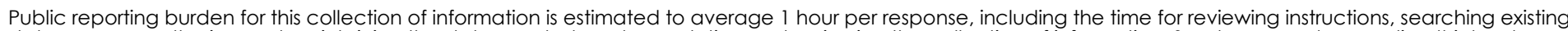

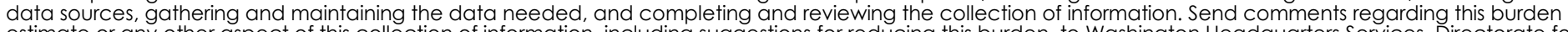

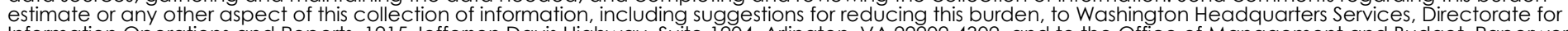

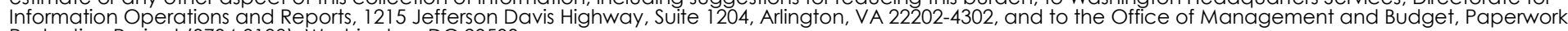
Reduction Project (0704-0188), Washington, DC 20503.

\begin{tabular}{|l|l|l}
\hline 1. AGENCY USE ONLY (Leave blank) & $\begin{array}{l}\text { 2. REPORT DATE } \\
\text { January } 2000\end{array}$ & $\begin{array}{l}\text { 3. REPORT TYPE AND DATES COVERED } \\
\text { Technical Report; August } 1998\end{array}$ \\
\hline
\end{tabular}

4. TITLE AND SUBTITLE

A Preliminary Analysis of Block Island Power Company's Use of Clean Distributed Resources to Provide Power to Its Customers; Technical Report; August 1998

6. AUTHOR(S)

T.E. Hoff

7. PERFORMING ORGANIZATION NAME(S) AND ADDRESS(ES)

Pacific Energy Group

32 Valla $\mathrm{Ct}$.

Walnut Creek, CA 94596

9. SPONSORING/MONITORING AGENCY NAME(S) AND ADDRESS(ES)

National Renewable Energy Laboratory

1617 Cole Blvd.

Golden, CO 80401-3393
5. FUNDING NUMBERS

C: XAX-6-16817-01

TA: PV008102

8. PERFORMING ORGANIZATION REPORT NUMBER

10. SPONSORING/MONITORING AGENCY REPORT NUMBER

SR-520-27513

11. SUPPLEMENTARY NOTES NREL Technical Monitor: C. Herig

12a. DISTRIBUTION/AVAILABILITY STATEMENT National Technical Information Service 12b. DISTRIBUTION CODE

U.S. Department of Commerce

5285 Port Royal Road

Springfield, VA 22161

13. ABSTRACT (Maximum 200 words)

This report is an analysis of the potential for Block Island Power Company (BIPCO) to use renewable energy and clean distributed resources to supply power to its customers. The preliminary conclusion of this work is that a system composed of clean distributed resources has the potential to be a technically and economically feasible alternative for BIPCO.
14. SUBJECT TERMS
15. NUMBER OF PAGES
photovoltaics ; renewable energy ; clean distributed resources
17. SECURITY CLASSIFICATION Unclassified OF REPORT
16. PRICE CODE
20. LIMITATION OF ABSTRACT
UL 